\title{
Improving Astronomy Achievement and Attitude through Astronomy Summer Project: A Design, Implementation and Assessment
}

\author{
Cumhur TÜRK ${ }^{1}$, Hüseyin KALKAN ${ }^{1}$, Nazan OCAK İSKELELİ ${ }^{1} \&$ Kasım KIROĞLU $^{2}$ \\ ${ }^{1}$ Science Education Program, Faculty of Education, Ondokuz Mayıs University, Samsun, Turkey \\ ${ }^{2}$ Primary Education Program, Faculty of Education, Ondokuz Mayıs University, Samsun, Turkey \\ Correspondence: Cumhur TÜRK, Science Education Program, Faculty of Education, Ondokuz Mayıs University, \\ 55200, Samsun, Turkey. Tel: 90-362-312-1919
}

Received: June 10, 2015

Accepted: November 17, 2015

Online Published: November 18, 2015

doi:10.5430/ijhe.v5n1p47

URL: http://dx.doi.org/10.5430/ijhe.v5n1p47

\begin{abstract}
The purpose of this study is to examine the effects of an astronomy summer project implemented in different learning activities on elementary school students, pre-service elementary teachers and in-service teachers' astronomy achievement and their attitudes to astronomy field. This study is the result of a five-day, three-stage, science school, "I Learn the Planet I Live on". The first stage involved astronomy science schools with 30 elementary school teachers, the second stage involved 30 pre-service elementary school teachers and the last stage involved 30 primary school pupils (aged 14). Within this scope, 30 elementary school teachers from different cities who are volunteer to participate in project, one seventh grade class of each of these teachers from their own schools and 30 pre-service teachers attending elementary department of education faculties of universities in Turkey are participated in the astronomy summer project in Samsun City in 2015 make up the sample of the study. For this purpose, within the scope of a nine-day long project, the participants were presented with hands on activities, outdoor practices, planetarium and observatory activities to enable them to view astronomy education from different views. The study was designed as one group, pre-test post-test experimental research. Astronomy attitude scale and astronomy achievement test were used as pre-test and post-test. The data obtained were evaluated using the SPSS 20.0 software package program. For the analysis of data, a parametric test, a two-way ANOVA for mixed measures, an experiment model, was used. The results of the study showed that the project was effective in increasing the participants' attitudes towards the astronomy field and their astronomy achievement. A comparison of the data from the teachers and the students produced interesting results, notably that more pupils than teachers answered certain questions correctly.
\end{abstract}

Keywords: Astronomy education, Astronomy concepts, Attitude, Education project

\section{Introduction}

Throughout the history of humankind, wonder of the Universe, attempts to uncover its secrets, and explain humans' position in it have existed. This curiosity necessarily entails questioning and learning nature's basic mechanisms and functioning (Türk \& Kalkan, 2015a). This process of questioning and learning involves various scientific methods particular to different cultures. Humans' curiosity about the shape and movements of the planet and its relations with the sun, the moon, and other planets is characteristic of the rise of scientific inquiry, of civilizations and cultures (Kalkan, et al, 2014). Scientific processes become meaningful not through rote learning but through comprehending the underlying basic mechanisms and causes. One of the fields, traditionally using memorization rather than internalized is, unfortunately, astronomy (Vosniadou \& Brewer 1985).

Eratosthenes, one of the most important actors in the development of natural sciences (BC 276), determined the Earth's shape, dimensions and position in the universe using simple methods with results close to the values measured by today's modern techniques (Sagan, 1980). All these processes contributed to our understanding of the planet we live on, our learning its certain basic characteristics, and thus to the development of the scientific processes. Although astronomy is the oldest science, studies related to astronomy education are not date back to old times. Studies related to astronomy education accelerated by the launch of Sputnik in 1957.

Because, in this process, the developed countries restructured science programs both in order not to stay behind in the space race and in order to reintegrate science concepts into the society. The most significant change in these 
programs was that astronomy education was ranked more when compared to the past. STAR Project in the United States is an example of this change. Likewise, astronomy education was featured by reorganizing science programs with the CLEA Project in France (Türk \& Kalkan, 2015b).

Astronomy education is a process starting with observation at the simplest level and proceeding with higher level thinking skills, in addition to this astronomy requires three dimensional and spatial thinking. Astronomy plays a central role for natural sciences in terms of being linked to the other basic sciences (e.g. physics, chemistry, geology and mathematics). However, when we look at the nature education projects in Turkey, it is seen that the projects for the environment and environmental education are more in number (Balım et al, 2013; Erdoğan, 2011; Güler, 2009; Oğurlu, Alkan \& Gündoğdu, 2010). Astronomy education projects as a nature education project are limited. Therefore, an astronomy education project has been planned for the gap required in the literature. The name of the project is as "I Learn the Planet I Live on" (ILPIL). Many middle school students, pre-service teachers and in-serive teachers were given education on subjects such as astronomy education, the methods and materials used in astronomy education and astronomy education resources with ILPIL project which has been supported for four years in a row since 2011 .

\subsection{Information about the Project and Implementation}

The nature education project titled ILPIL is a project which is worth being supported by The Scientific and Technological Research Council of Turkey (STRCT) for the fourth time. The project has been carried out in Ondokuz Mayıs University Astronomy Center. Project participants are selected among the candidates who applied voluntarily. The middle school students, pre-service teachers and in-service teachers in the project are taken in different camps for three days. The educational content of each camp is in parallel. The project which was prepared in accordance with the philosophy that we need to have a better understanding of the Earth we live on and the universe we are in is carried out in two stages with the activities titled "Astronomy Science School" and "Measuring the Circumference of Earth".

\section{Learn the Planet I Live on IV}

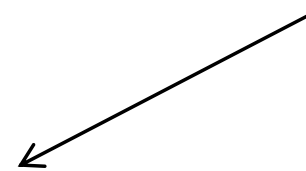

Astronomy Science School

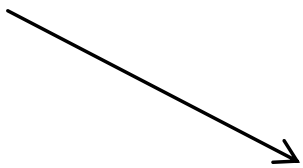

Measuring the Circumference of Earth

- Astronomy Science School with Students

- Astronomy Science School with Pre-Service Teachers

- Astronomy Science School with In-Service Teachers

Astronomy Science School: Astronomy Science School activity which was held in Ondokuz May1s University Astronomy Center was conducted in three stages. These were "Astronomy Science School with Students" and "Astronomy Science School with in-service Teachers" and "Astronomy Science School with Pre-service Teachers".

Astronomy Science School with Students: Astronomy Science School with Students was conducted with middle school students because, basic astronomy subjects are covered intensively in the primary and middle school programs in Turkish Education system. It gets more difficult in later age levels to correct the alternative conceptions about basic astronomy concepts in primary and middle school students. Implementations of the students from only the middle schools which were in the town (Samsun city) where the project was conducted were accepted for this science school. Astronomy Science School with Students was conducted with 30 middle school students and lasted three days.

Astronomy Science School with Pre-Service Teachers: Astronomy Science School with Pre-service Teachers which was carried out with 30 pre-service teachers selected among the implementations made from all of the cities in Turkey and lasted 3 days. It was planned to disseminate and encourage such activities into the education system in the future by involving 30 pre-service teachers from education faculties in Turkey into the project.

Astronomy Science School with In-Service Teachers: Astronomy Science School with Teachers was carried out with 30 teachers selected among the implementations made from all of the cities of Turkey and lasted 3 days. Science teachers and the Primary School teachers were selected primarily as the target audience. The main reason for this is that basic astronomy subjects are taught by Science teachers and Primary teachers in the Turkish education system. 
Measuring the Circumference of Earth Activity: "Measuring the Circumference of Earth" activity which is the basic starting point of our project allowed the middle school students to carry out their own measurements to measure the diameter of the Earth which Eratosthenes performed by measuring the shadow length of the sun rays in Alexandria and Syene in Egypt in BC 276 years. The target audience of this activity was middle school students chosen from the schools where the teachers who participated in the Project's Astronomy Science School with Teachers activity work. The teachers who work in the cities which are in the same (approximately) longitude were matched during Astronomy Science School with Teachers. They were announced as sister cities of one another. In this way, 15 different lines (sister cities) were identified in Turkey. Measuring the Circumference of Earth activity was conducted by the teachers who work in these sister cities and their students on June 11, 2015 when the Sun passed in transit (which is directly overhead) in the sky.

$>$ When creating the project content, the content of the activities was formed by taking the characteristics of the target audience into consideration. "Activity selection criteria" was identified by the project team while determining the activities. The following criteria was taken into account in order to determine science and nature implementations which would be carried out for student-centered science teaching as part of the project:

- It was regarded that the activities matched the age and development level of the $8^{\text {th }}$ grade of students.

- It was regarded that the activities were appropriate to the basic astronomy subjects while determining them.

- It was regarded in what subjects the students had or did not have alternative conception by examining the studies in the literature.

- It was regarded that the activities were appropriate to and supportive for middle school Science lesson curriculum content.

- It was noted that the students were familiarized to the university environment thanks to the activities which were carried out in Ondokuz Mayis University campus area (Astronomy Center).

- The opinions received from the participants about the activities were regarded at the end of the "I Learn the Planet I live on I, II and III" projects which were conducted in 2011, 2012 and 2014. The activities which attracted the participants' attention and increased their motivation were included in the new project implementation after rearranged. New activities were added in accordance with the opinions of the participants and the project team.

- It was noted whether the activities could attract the participants' attention or not.

- Financial aspect of the materials to be used in the activities was regarded.

An activity pool was determined in accordance with all these criteria. The project manager and expert personnels met and decided which activities in the activity pool would be used in the project in accordance with the criteria above.

\subsection{Implementation Schedule and Activities}

Astronomy science schools were planned for three days. Camps were carried out for students, pre-service teachers and in-service teachers on different dates. However, the activities in the camps were the same for all groups. Besides, different theme was planned for each days and teaching environment, teaching methods and activities appropriate to the themes were determined. Daily themes of the project ILPIL, teaching environment, teaching methods and activities are presented in detail in Table 1. 
Table 1. The themes and activities in ILPIL project

\begin{tabular}{|c|c|c|c|c|}
\hline Days & Theme & $\begin{array}{l}\text { Learning } \\
\text { Environment }\end{array}$ & Method & Activities \\
\hline \multirow{5}{*}{$1^{\text {st }}$} & \multirow{5}{*}{ Planetarium Implementations } & \multirow{5}{*}{ Planetarium } & \multirow{5}{*}{ 3D simulation } & - Finding direction in the sky \\
\hline & & & & $\begin{array}{l}\text { - Planetarium screening (The } \\
\text { Oasis in the Universe) }\end{array}$ \\
\hline & & & & $\begin{array}{l}\text { - Planetarium Screening (The } \\
\text { Astronaut) }\end{array}$ \\
\hline & & & & - The Constellations \\
\hline & & & & - Latitude and longitudes \\
\hline \multirow[t]{2}{*}{$1^{\text {st }}$} & \multirow{2}{*}{ Observatory Implementations } & \multirow[t]{2}{*}{ Observatory } & \multirow{2}{*}{ Observation } & $\begin{array}{l}\text { - Observing the Sun, Moon and } \\
\text { Planets }\end{array}$ \\
\hline & & & & - Finding the constellations \\
\hline \multirow{6}{*}{$2^{\text {nd }}$} & \multirow{6}{*}{ Hands-on Implementations } & \multirow{6}{*}{$\begin{array}{l}\text { Workshop } \\
\text { classroom }\end{array}$} & \multirow{6}{*}{$\begin{array}{l}\text { Hands on } \\
\text { learning }\end{array}$} & - Making Galilescope \\
\hline & & & & - Solar and Lunar eclipse \\
\hline & & & & - Formation of seasons \\
\hline & & & & - Phases of Moon \\
\hline & & & & - The Constellations \\
\hline & & & & $\begin{array}{l}\text { - Measuring the Circumference } \\
\text { of Earth }\end{array}$ \\
\hline \multirow{5}{*}{$3^{\text {rd }}$} & \multirow{5}{*}{ Classroom Implementations } & \multirow{5}{*}{ Classroom } & \multirow{5}{*}{$\begin{array}{l}\text { Documentary } \\
\& \\
\text { Presentations }\end{array}$} & - Big-bang \\
\hline & & & & $\begin{array}{l}\text { - Astronomy Resources on the } \\
\text { Internet }\end{array}$ \\
\hline & & & & - The Universe and Us \\
\hline & & & & $\begin{array}{l}\text { - Documentary screening } \\
\text { (Cosmic Voyage) }\end{array}$ \\
\hline & & & & $\begin{array}{l}\text { - Documentary screening (The } \\
\text { Cold Face of Change) }\end{array}$ \\
\hline
\end{tabular}

\subsection{The Purpose of Research}

The aim of the study is to analyze the astronomy achievement of the students, pre-service teachers and in-service teachers who participated in the study and the changes in their attitudes to astronomy. In addition, it is to study the students, pre-service teachers and in-service teachers' astronomy achievement and their attitude to astronomy by making intergroup comparisons during the project.

"What is the impact of ILPIL project on the participants' astronomy achievement and their attitude to astronomy?"

"What is the relationship between the students, pre-service teachers and in-service teachers' astronomy achievement and their attitudes towards astronomy?"

1. What kind of changes occurred in the participants' astronomy achievement pre- and post-project?

2. What is the change in the participants' astronomy achievement in comparison with the groups?

3. What kind of change occurred in the participants' attitudes to astronomy pre- and post-project?

4. What is the change in the participants' attitudes to the astronomy in comparison with the groups?

\section{Method}

This study was designed in a single group (without control group) pre-test post-test experimental research design. In this design, the effect of the experimental method is tested by the study carried out on a single group and the subjects' measurements regarding dependent variables are obtained by pre-test before the implementation and by post-test after the implementation using the same subjects and the same measuring instruments (Fraenkel, Wallen, \& Hyun, 
2012). Since the study was conducted with students, pre-service teachers and in-service teachers who participated in the astronomy education project, there was not a control group in the study.

In addition, in this study it is aimed to determine the similarity and differences of the middle school students, pre-service teachers and in-service teachers' achievements in astronomy subjects and their attitude to astronomy. When viewed from this aspect the study has a survey aspect. Survey research designs are procedures in quantitative research in which investigators administer a survey to a sample or to the entire population of people to describe the attitudes, opinions, behaviors, or characteristics of the population (Creswell, 2008). In this research the data collected at just one point in time using cross sectional survey which is one of the survey designs. The cross sectional survey collects information from a sample that has been drawn from a predetermined population (Fraenkel, Wallen, and Hyun, 2012).

\subsection{Sample}

The sample of the study is students, prospective teachers and teachers who participated voluntarily in the ILPIL project which was conducted in Samsun in 2015 and supported by the program of STRCT Nature Education Sciences School for the fourth time. The information on the demographic characteristics of the participants is presented in Table 2.

Table 2. Demographic Characteristics of the Participants

\begin{tabular}{cccc}
\hline & \multicolumn{3}{c}{ Gender } \\
\hline Group & Female & Male & Total \\
\hline Student & 15 & 15 & 30 \\
Pre-Service Teacher & 16 & 14 & 30 \\
In-Service Teacher & 17 & 13 & 30 \\
\hline
\end{tabular}

\subsection{The Data Collecting Instruments}

Two different data collection tools were used for the purpose of the study. These are "Astronomy Achievement Test" and "Astronomy Attitude Scale". Information on these two data collection tools is given in detail below.

\subsubsection{Astronomy Achievement Test}

Astronomy Achievement Test (AAT) which was developed by Türk \& Kalkan (2015b) was used in order to measure the participants' achievements in astronomy subjects. This test is a valid and reliable test to measure the achievement of basic astronomy concepts. The average difficulty of the test consisting four-choice 32 items was calculated as 0.51 , the average distinctiveness as 0.51 and KR-20 reliability coefficient was calculated as 0.87 . In calculating the results obtained from the academic achievement test; the total test score of each student was calculated by evaluating correct answers as 1 point, wrong answers, missing items or those who marked more than one answer for the same item as 0 point.

\subsubsection{Astronomy Attitude Scale}

The Astronomy Attitude Scale (AAS) was used to determine the participants' attitudes to astronomy consisting of their feelings, opinions and behaviors and to compare their changes at the end of the project. 5 points Likert Scale developed by Türk \& Kalkan (2015c) was used for the attitude to astronomy. The Likert scale ranged from: Totally agree (5), Agree (4) Indecisive (3), Disagree (2) totally disagree (1). The scale consisted 27 items (17 positive - 10 negative) and Cronbach-Alpha internal consistency coefficient was 0,912.

\subsection{Data Analyses}

SPSS 22.0 statistics program was used for quantitative data obtained by applying the AAT and AAS. These tests were applied to participants twice before the project (pre-test) and after the project (post-test). Before the statistical analysis was conducted, descriptive statistics were calculated for the scores which the students, pre-service teachers and in-service teachers gained from each test. Then, tests of data normality were conducted to determine whether to use parametric or non-parametric data analysis techniques for data analysis.

Normality tests were conducted in order to test the astronomy achievement test's suitability to normal distribution (Kolmogorov-Smirnov and Shapiro-Wilk). The results of these tests are given in Table 3. 
Table 3. Normality Test Results for the AAT

\begin{tabular}{|c|c|c|c|c|c|c|c|}
\hline \multirow[b]{2}{*}{ Test } & \multirow[b]{2}{*}{ Group } & \multicolumn{3}{|c|}{ Kolmogorov-Smirnov } & \multicolumn{3}{|c|}{ Shapiro-Wilk } \\
\hline & & Statistic & df & Sig. & Statistic & df & Sig. \\
\hline \multirow{3}{*}{ Pre-Test } & Student &, 124 & 30 & ,200* & ,977 & 30 &, $727 *$ \\
\hline & Pre-service Teacher & ,089 & 30 &, $200 *$ & ,976 & 30 &, $715^{*}$ \\
\hline & In-service Teacher & ,094 & 30 &, $183^{*}$ & ,914 & 30 &, $718^{*}$ \\
\hline \multirow{3}{*}{ Post-Test } & Student &, 145 & 30 &, $110^{*}$ & ,957 & 30 & ,263* \\
\hline & Pre-service Teacher &, 134 & 30 &, $180 *$ & ,970 & 30 &, $543^{*}$ \\
\hline & In-service Teacher &, 101 & 30 &, $190 *$ & ,938 & 30 &, $245^{*}$ \\
\hline
\end{tabular}

$* \mathrm{p}>0,05$

When Table 3 is viewed, that the p-value is higher than 0.05 is interpreted as the scores at this significance level do not have a significance (extreme) deviation from the normal distribution that is to say it is interpreted as appropriate (Büyüköztürk, 2007, 2010). Accordingly, it is seen from the Kolmogorov-Smirnov and Shapiro-Wilk test results that the participants' (for all groups) astronomy achievement test scores do not differ significantly from the normal distribution ( $\mathrm{P}>0.05)$. Thus, parametric analysis techniques were decided to be used in the analysis of AAT data.

Normality test results for the AAS are given in Table 4.

Table 4. Normality Test Results for the AAS

\begin{tabular}{cccccccc}
\hline & & \multicolumn{2}{c}{ Kolmogorov-Smirnov } & \multicolumn{3}{c}{ Shapiro-Wilk } \\
\hline Test & Group & Statistic & df & Sig. & Statistic & df & Sig. \\
\hline \multirow{2}{*}{ Pre-Test } & Student &, 151 & 30 &, $080^{*}$ &, 918 & 30 &, $074^{*}$ \\
& Pre-Service Teacher &, 098 & 30 &, $200^{*}$ &, 980 & 30 &, $813^{*}$ \\
& In-Service Teacher &, 134 & 30 &, $178^{*}$ &, 954 & 30 &, $221^{*}$ \\
\hline \multirow{2}{*}{ Post-Test } & Student &, 145 & 30 &, $107^{*}$ &, 951 & 30 &, $184^{*}$ \\
& Pre-Service Teacher &, 129 & 30 &, $200^{*}$ &, 960 & 30 &, $311^{*}$ \\
& In-Service Teacher &, 171 & 30 &, $076^{*}$ &, 894 & 30 &, $066^{*}$ \\
\hline
\end{tabular}

$* \mathrm{p}>0,05$

When Table 4 is observed it is seen that the data shows a normal distribution for all groups. Thus parametric analysis techniques were decided to be used in the analysis of AAS data.

In the study; mixed design Anova technique was used for repeated measures in order to compare the changes (if any) in the students, pre-service teachers and in-service teachers' astronomy achievements and their attitude to astronomy before and after the project. The comparison of the results of the group measurement is a measurement for unrelated samples and the implementation of the pretest first and then the posttest to the students, pre-service teachers and in-service teachers is a repeated measurement for related samples. Two different implementations are in question as both the measurement of different groups and the measurement of the same group repeatedly. Therefore, it is called as variance analysis for mixed measurements for such procedures. Here, the groups constitute one of the directions (factors), the measurements constitute the other one (Can, 2014).

A single factor variance analysis (One-Way Anova) technique for independent groups was used in order to demonstrate whether there was a significant difference between the groups' AAT and AAS and pre-test and post-test scores. The Single factor (way) variance analysis is conducted in order to test whether or not the difference between the averages of unrelated two or more samples is significantly different from zero (Büyüköztürk, 2007, 2010).

Single factor variance analysis technique was used for repeated measures in order to demonstrate whether there was a significant difference between AAT and AAS, pre-test and post-test scores within the groups themselves. One way variance analysis is the test to be conducted in order to determine whether there is a significant difference between the data averages gained as a result of the successive measures from the same data source. 
Significance level was taken as 0.05 when interpreting the results of the statistical analysis. Eta square ( $\eta 2)$ values which show the effect size were calculated to test the effect of the independent variables on each dependent variable. Reviews of Eta square values are as; 0.10 shows small; 0.24 medium and 0.31 shows high effect (Cohen, 1988).

\section{Findings}

The findings pre- and post-project related to the participants' astronomy achievement and their attitude are given as subheadings. First descriptive findings, then pre- and post-project findings as inter-group and intra-group findings and finally mixed design variance analysis are given while presenting the findings.

\subsection{Findings Related to Astronomy Achievement}

Descriptive statistics related to the astronomy achievement of participants are given in Table 5.

Table 5. Descriptive Statistics Related to the Astronomy Achievement

\begin{tabular}{ccccccc}
\hline Test & Group & N & Mean & $\begin{array}{c}\text { Std. } \\
\text { Deviation }\end{array}$ & Skewness & Kurtosis \\
\hline \multirow{3}{*}{ Pre-Test } & Student & 30 & 17,73 & 4,44843 & 0,007 & 0,588 \\
& $\begin{array}{c}\text { Pre-Service } \\
\text { Teacher }\end{array}$ & 30 & 15,97 & 5,02740 & 0,433 & $-0,842$ \\
& In-Service Teacher & 30 & 21,03 & 3,32683 & $-1,088$ & $-1,273$ \\
\hline \multirow{2}{*}{ Post-Test } & Student & 30 & 20,93 & 4,47162 & $-1,001$ & $-0,764$ \\
& $\begin{array}{c}\text { Pre-Service } \\
\text { Teacher }\end{array}$ & 30 & 21,06 & 3,66656 & $-0,606$ & $-0,570$ \\
& In-Service Teacher & 30 & 23,93 & 3,11762 & $-1,627$ & 1,901 \\
\hline
\end{tabular}

According to Table 5 the in-service teacher group has the highest average for astronomy achievement both in the pre- and the post-test. While middle school students were more successful than the pre-service teachers in the pre-test results, the pre-service teachers had a higher achievement average than the middle school students in the post-test. Overall, astronomy achievement scores of all groups showed an increase in the post-test.

One way variance analysis was conducted for the unrelated samples to see whether or not the participants' pre-test astronomy achievement scores differentiated significantly from one another in comparison with the groups, the results are given in Table 6 .

Table 6. One-way Variance Analysis Results of the Astronomy Achievement Pre-Test Results

\begin{tabular}{lccccc}
\hline Source of Variance & $\begin{array}{c}\text { Sum of } \\
\text { Squares }\end{array}$ & df & $\begin{array}{c}\text { Mean } \\
\text { Squares }\end{array}$ & F & p \\
\hline Between Groups & 396,822 & 2 & 198,411 & 10,604 &, $\mathbf{0 0 0 *}$ \\
Within Groups & 1627,800 & 87 & 18,710 & & \\
Total & 2024,622 & 89 & & & \\
$* \mathrm{p}<0.05$ & & & & &
\end{tabular}

According to Table 6, there is a significant difference between the participants' pre-test astronomy achievement scores in comparison with the groups $\left(\mathrm{F}_{2-89}=10.604, \mathrm{p}<0.05\right)$. This finding can be interpreted as the participants' astronomy achievement changed significantly in comparison with the groups.

The findings relating to between which groups there was a significant difference as a result of paired comparison of the participants' pre-test astronomy achievement scores are given in Table 7. While ANOVA was conducted for this finding, paired comparison (bonferroni) was conducted after one-way variance analysis. 
Table 7. Paired Comparison of Pre-Test of Astronomy Achievement Test

\begin{tabular}{ccccc}
\hline & & Mean Difference & Std. Deviation & p \\
\hline \multirow{2}{*}{ Student } & $\begin{array}{c}\text { Pre-Service } \\
\text { Teacher }\end{array}$ & 1,76667 & 1,11685 &, 352 \\
& In-Service Teacher & $-3,30000$ & 1,11685 &, $\mathbf{0 1 2} *$ \\
\hline Pre-Service & Student & $-1,76667$ & 1,11685 &, 352 \\
Teacher & In-Service Teacher & $-5,06667$ & 1,11685 &, $\mathbf{0 0 0}$ \\
\hline \multirow{2}{*}{ In-Service } & Student & 3,30000 & 1,11685 &, $\mathbf{0 1 2} *$ \\
Teacher & Pre-Service & 5,06667 & 1,11685 &, $\mathbf{0 0 0}^{*}$ \\
\hline p $<0.05$ & Teacher & & &
\end{tabular}

When Table 7 is analyzed it is seen that there is a significant difference between the pretest astronomy achievement scores of the middle school students and in-service teachers $(\mathrm{p}<0.05)$. When the averages are considered it is seen that this difference is in favor of teachers.

When the difference between pre-service teachers and in-service teachers' pre-test astronomy achievement scores is examined, it is found that there is a significant difference $(\mathrm{p}<0.05)$. Considering the averages, it is observed that this difference is in favor of in-service teachers.

Finally, when the difference between the pre-test astronomy achievement scores of the middle school students and pre-service teachers is examined, it is found that there is not a statistically significant difference between measurements $(\mathrm{p}>0.05)$.

One-way variance analysis was conducted for unrelated samples to see whether or not the participants' astronomy achievement post-test scores differentiated significantly from one another in comparison with the groups and the results are given in Table 8 .

Table 8. One-way Variance Analysis Results of the Astronomy Achievement Post-Test Results

\begin{tabular}{lccccc}
\hline Source of Variance & $\begin{array}{c}\text { Sum of } \\
\text { Squares }\end{array}$ & df & $\begin{array}{c}\text { Mean } \\
\text { Squares }\end{array}$ & F & p \\
\hline Between Groups & 172,356 & 2 & 86,178 & 5,990 & $\mathbf{, 0 0 4} *$ \\
Within Groups & 1251,600 & 87 & 14,386 & & \\
Total & 1423,956 & 89 & & & \\
\hline p $<0.05$ & & & &
\end{tabular}

According to Table 8, there is a significant difference between the participants' post-test astronomy achievement scores in comparison with the groups $\left(\mathrm{F}_{2-89}=5.990, \mathrm{p}<0.05\right)$. This finding can be interpreted as the participants' astronomy achievement changed significantly when compared to the groups.

The findings for between which groups there is a significant difference as a result of the paired comparison of the participants' astronomy achievement posttest scores is presented in Table 9.

Table 9. Paired Comparison of Post-Test of Astronomy Achievement Test

\begin{tabular}{|c|c|c|c|c|}
\hline & & Mean Difference & Std. Deviation & $\mathbf{p}$ \\
\hline \multirow[t]{2}{*}{ Student } & $\begin{array}{l}\text { Pre-Service } \\
\text { Teacher }\end{array}$ &,- 13333 & ,97933 & 1,000 \\
\hline & In-Service Teacher & $-3,00000$ & ,97933 &, $009 *$ \\
\hline \multirow{2}{*}{$\begin{array}{l}\text { Pre-Service } \\
\text { Teacher }\end{array}$} & Student &, 13333 & ,97933 & 1,000 \\
\hline & In-Service Teacher & $-2,86667$ & 97933 &, $013 *$ \\
\hline \multirow{2}{*}{$\begin{array}{l}\text { In-Service } \\
\text { Teacher }\end{array}$} & Student & 3,00000 & ,97933 &, $009 *$ \\
\hline & $\begin{array}{c}\text { Pre-Service } \\
\text { Teacher }\end{array}$ & 2,86667 & ,97933 &, $013 *$ \\
\hline
\end{tabular}


When Table 9 is analyzed, it is seen that there is a significant difference between the post-test astronomy achievement scores of middle school students and in-service teachers $(p<0.05)$. Considering the averages it is seen that this difference is in favor of in-service teachers.

When the difference between the post-test astronomy achievement scores of pre-service teachers and the in-service teachers is analyzed, it is found that there is a statistically significant difference $(\mathrm{p}<0.05)$. Considering the averages it is seen that this difference is in favor of in-service teachers.

Finally, when the difference between post-test astronomy achievement scores of middle school students and pre-service teachers is analyzed, it is seen that there is not a statistically significant difference between the measurements ( $p>0.05)$.

The variance analysis results for whether or not the change in the students, pre-service teachers and in-service teachers' scores of astronomy achievement test show a significant difference are shown in Table 10.

Table 10. Variance Analysis Results of Astronomy Achievement Scores

\begin{tabular}{|c|c|c|c|c|c|c|}
\hline Source of Variance & $\begin{array}{l}\text { Sum of } \\
\text { Squares }\end{array}$ & df & Mean Squares & $\mathbf{F}$ & $\mathbf{p}$ & $\eta^{2}$ \\
\hline Between Groups & 2434,778 & 89 & & & & \\
\hline Group & 526,478 & 2 & 263,239 & 12,001 &, $000^{*}$ & 0,216 \\
\hline Error & 1908,300 & 87 & 21,934 & & & \\
\hline Within Groups & 1641,000 & 90 & & & & \\
\hline $\begin{array}{l}\text { Measure } \\
\text { (Pre_Post_Test) }\end{array}$ & 627,200 & 1 & 627,200 & 56,190 &, $000^{*}$ & 0,392 \\
\hline Group* Measure & 42,700 & 2 & 21,350 & 1,913 &, 154 & 0,042 \\
\hline Error & 971,100 & 87 & 11,162 & & & \\
\hline Total & 4075,778 & 179 & & & & \\
\hline
\end{tabular}

When Table 10 is analyzed it is seen that between groups astronomy achievement scores show a significant difference regardless of measuring factors $\left(\mathrm{F}_{\text {Group }}=12.001, \mathrm{p}<0.05\right)$. This finding shows that there is a significant difference between the astronomy achievement scores of the students, pre-service teachers and in-service teachers without discriminating between pre- and post-tests.

There is a significant difference between the students, pre-service teachers and in-service teachers' astronomy achievement pre- and post-test average scores $\left(\mathrm{F}_{\text {Measurement }}=56.190, \mathrm{p}<0.05\right)$. According to this finding, it can be said that the astronomy achievement of all the participants changed significantly according to the measurements without discriminating between the groups.

Finally, it is seen that the participants' astronomy achievements do not show a significant difference after the project than it was before the project, that is to say that the mutual effect of the factors of being in a different procedure group and repeated measurements on astronomy achievement is not significant $\left(\mathrm{F}_{\text {Group } * \text { Measurement }}=1.913, \mathrm{p}>0.05\right)$ This finding shows that the implementation conducted in different groups have different effects in increasing the astronomy achievement of the groups.

In addition, when the effect size $\left(\eta^{2}\right)$ values of the study are analyzed, 0.216 is calculated for between group measurements and 0.392 calculated for within measurements. These values indicate that the project implementations have a high level of effect size in increasing the participants' astronomy achievements. 


\subsection{Findings Related to the Attitudes to Astronomy}

Descriptive statistics for the participants' attitudes to astronomy are given in Table 11.

Table 11. Descriptive Statistics of Attitudes to Astronomy

\begin{tabular}{ccccccc}
\hline Test & Group & N & Mean & $\begin{array}{c}\text { Std. } \\
\text { Deviation }\end{array}$ & Skewness & Kurtosis \\
\hline \multirow{2}{*}{ Pre-Test } & $\begin{array}{c}\text { Student } \\
\text { Pre-Service } \\
\text { Teacher }\end{array}$ & 30 & 104,07 & 10,39872 & $-1,185$ & 0,668 \\
& In-Service Teacher & 30 & 112,83 & 7,38630 & 0,482 & $-0,785$ \\
\hline Post-Test & $\begin{array}{c}\text { Student } \\
\text { Pre-Service }\end{array}$ & 30 & 109,27 & 10,21133 & $-1,283$ & $-0,251$ \\
& $\begin{array}{c}\text { Teacher } \\
\text { In-Service Teacher }\end{array}$ & 30 & 110,60 & 10,96263 & $-0,227$ & $-0,982$ \\
& 30 & 116,53 & 8,71279 & 0,182 & $-1,925$ \\
\hline
\end{tabular}

According to the Table 11, in-service teachers group is the group who has the highest average in both pre- and post-test. It is seen that the attitudes of middle school students and pre-service teachers are close pre- and post-project. Generally, the attitudes to astronomy of all groups showed an increase in the post-test.

One-way variance analysis was conducted for unrelated samples to see whether or not participants' pre-test astronomy attitude scores differentiated significantly from one another in comparison with the groups, the results are given in Table 12.

Table 12. The Results of One-Way Variance Analysis of AAS Pre-Tests

\begin{tabular}{lccccc}
\hline Source of Variance & $\begin{array}{c}\text { Sum of } \\
\text { Squares }\end{array}$ & df & $\begin{array}{c}\text { Mean } \\
\text { Squares }\end{array}$ & F & p \\
\hline Between Groups & 1322,956 & 2 & 661,478 & 7,399 & ,001* \\
Within Groups & 7777,500 & 87 & 89,397 & & \\
Total & 9100,456 & 89 & & & \\
$* 0.05$ & & & & &
\end{tabular}

According to the Table 12 there was a significant difference between the participants' attitude pre-test scores considering the groups $\left(\mathrm{F}_{2-89}=7.399, \mathrm{p}<0.05\right)$. This finding can be interpreted as the participants' attitudes to astronomy changed significantly considering the groups before the project.

The findings relating to between which groups there were significant differences as a result of the paired comparison of the participants' pre-test astronomy attitude scores are presented in Table 13.

Table 13. Paired Comparison of AAS Pre-Test Scores

\begin{tabular}{|c|c|c|c|c|}
\hline & & Mean Difference & Std. Deviation & $\mathbf{p}$ \\
\hline \multirow[t]{2}{*}{ Student } & $\begin{array}{c}\text { Pre-Service } \\
\text { Teacher }\end{array}$ & $-1,46667$ & 2,44126 & 1,000 \\
\hline & In-Service Teacher & $-8,76667$ & 2,44126 &, $002 *$ \\
\hline \multirow{2}{*}{$\begin{array}{l}\text { Pre-Service } \\
\text { Teacher }\end{array}$} & Student & 1,46667 & 2,44126 & 1,000 \\
\hline & In-Service Teacher & $-7,30000$ & 2,44126 &, $011 *$ \\
\hline \multirow{2}{*}{$\begin{array}{l}\text { In-Service } \\
\text { Teacher }\end{array}$} & Student & 8,76667 & 2,44126 &, $002 *$ \\
\hline & $\begin{array}{c}\text { Pre-Service } \\
\text { Teacher }\end{array}$ & 7,30000 & 2,44126 &, $011 *$ \\
\hline
\end{tabular}


When Table 13 is analyzed it is seen that there is a significant difference between the pre-test astronomy attitude scores of middle school students and in-service teachers $(p<0.05)$. Considering the averages it is seen that this difference is in favor of in-service teachers.

When the difference between the astronomy attitude pre-test scores of pre-service teachers and in-service teachers is analyzed, it is found that there is a statistically significant difference $(\mathrm{p}<0.05)$. Considering the averages it is observed that this difference is in favor of in-service teachers.

Finally, when the difference between the pre-test astronomy attitude scores of middle school students and pre-service teachers is analyzed, it is seen that there is not a statistically significant difference between measurements ( $p>0.05)$.

One-way variance analysis was conducted for unrelated samples to see whether or not participants' post-test astronomy achievement scores differentiated significantly from one another in comparison with the groups, the results are given in Table 14.

Table 14. The Results of One-Way Variance Analysis of AAS Post-tests

\begin{tabular}{lccccc}
\hline Source of Variance & $\begin{array}{c}\text { Sum of } \\
\text { Squares }\end{array}$ & df & $\begin{array}{c}\text { Mean } \\
\text { Squares }\end{array}$ & F & p \\
\hline Between Groups & 897,867 & 2 & 448,933 & 4,484 & \multirow{2}{*014*}{} \\
Within Groups & 8710,533 & 87 & 100,121 & & \\
Total & 9608,400 & 89 & & & \\
${ }_{\mathrm{p}}<0.05$ & & & & &
\end{tabular}

According to the Table 14 there was a significant difference between the participants' attitude post-test scores considering the groups $\left(\mathrm{F}_{2-89}=4,484, \mathrm{p}<0.05\right)$. This finding can be interpreted as the participants' attitudes to astronomy changed significantly considering the groups after the project.

The findings relating to between which groups there were significant differences as a result of the paired comparison of the participants' post-test astronomy attitude scores are presented in Table 15.

Table 15. Paired Comparison of AAS Post-Test Scores

\begin{tabular}{|c|c|c|c|c|}
\hline & & Mean Difference & Std. Deviation & $\mathbf{p}$ \\
\hline \multirow[t]{2}{*}{ Student } & $\begin{array}{c}\text { Pre-Service } \\
\text { Teacher }\end{array}$ & $-1,33333$ & 2,58355 & 1,000 \\
\hline & In-Service Teacher & $-7,26667^{*}$ & 2,58355 & ,018* \\
\hline \multirow{2}{*}{$\begin{array}{c}\text { Pre-Service } \\
\text { Teacher }\end{array}$} & Student & 1,33333 & 2,58355 & 1,000 \\
\hline & In-Service Teacher & $-5,93333$ & 2,58355 & ,072 \\
\hline \multirow{2}{*}{$\begin{array}{l}\text { In-Service } \\
\text { Teacher }\end{array}$} & Student & 7,26667 & 2,58355 & ,018* \\
\hline & $\begin{array}{c}\text { Pre-Service } \\
\text { Teacher }\end{array}$ & 5,93333 & 2,58355 & ,072 \\
\hline
\end{tabular}

When Table 15 is analyzed it is seen that there is a significant difference between the post-test astronomy attitude scores of middle school students and in-service teachers $(p<0.05)$. Considering the averages it is seen that this difference is in favor of in-service teachers.

When the difference between the astronomy attitude post-test scores of pre-service teachers and in-service teachers is analyzed, it is found that there is not a statistically significant difference between measurements $(p>0.05)$.

Finally, when the difference between the post-test astronomy attitude scores of middle school students and pre-service teachers is analyzed, it is seen that there is not a statistically significant difference between measurements ( $>0.05)$.

The variance analysis results for whether or not the change in the students, pre-service teachers and in-service teachers' astronomy attitude scores show a significant difference are shown in Table 16. 
Table 16. Variance Analysis Results of Astronomy Attitude Scores

\begin{tabular}{lcccccc}
\hline Source of Variance & $\begin{array}{c}\text { Sum of } \\
\text { Squares }\end{array}$ & df & Mean Squares & $\mathbf{F}$ & $\mathbf{p}$ & $\boldsymbol{\eta}^{\mathbf{2}}$ \\
\hline Between Groups & 14590,694 & 89 & & & & \\
Group & 2200,144 & 2 & 1100,072 & 7,724 & $\mathbf{, 0 0 1 *}$ &, 151 \\
Error & 12390,550 & 87 & 142,420 & & & \\
Within Groups & 5093,500 & 90 & & & & \\
Measure & 975,339 & 1 & 975,339 & 20,709 & $\mathbf{, 0 0 0}$ &, 192 \\
(Pre_Post_Test) & 20,678 & 2 & 10,339 &, 220 &, 803 & \\
Group* Measure & 4097,483 & 87 & 47,098 & & & \\
Error & 19684,194 & 179 & & & & \\
Total & & & & & & \\
* & & & & & &
\end{tabular}

When Table 16 is analyzed it is seen that between groups astronomy attitude scores show a significant difference regardless of measuring factors $\left(\mathrm{F}_{\text {Group }}=7,724, \mathrm{p}<0,05\right)$. This finding shows that there is a significant difference between the astronomy attitude scores of the students, pre-service teachers and in-service teachers without discriminating between pre- and post-tests.

There is a significant difference between the students, pre-service teachers and in-service teachers' attitude to astronomy pre- and post-test average scores $\left(\mathrm{F}_{\text {Measurement }}=20,709, \mathrm{p}<0,05\right)$. According to this finding, it can be said that the attitude to astronomy of all the participants changed significantly according to the measurements without discriminating between the groups.

Finally, it is seen that the participants' attitudes to astronomy do not show a significant difference after the project than it was before the project, that is to say that the mutual effect of the factors of being in a different procedure group and repeated measurements on astronomy attitude is not significant $\left(\mathrm{F}_{\text {Group*Measurement }}=0,220, \mathrm{p}>0,05\right)$ This finding shows that the implementation conducted in different groups have different effects in increasing the attitude to astronomy of the groups.

In addition, when the effect size $\left(\eta^{2}\right)$ values of the study are analyzed, 0.151 is calculated for between group measurements and 0.192 calculated for within measurements. These values indicate that the project implementations have a middle level of effect size in increasing the participants' attitudes to astronomy.

\section{Discussion}

While there was not a significant difference between the astronomy achievement of the middle school students and the pre-service teachers before the project, it was concluded that the teachers were more successful than both the students and the pre-service teachers. In addition, another interesting pre-project result is that the students were more successful than the pre-service teachers. After the project implementations the difference between the students and the pre-service teachers was made up and the pre-service teachers were found to be more successful relatively. The teachers were more statistically significant successful than both students and the pre-service teachers after the project as well as before the project. But, it is remarkable that there is not a big difference between the teachers' average of astronomy achievement and the students and the pre-service teachers' astronomy achievement averages. However, when the results between the students and the pre-service teachers are analyzed, the reason why the students were more successful than the pre-service teachers is thought to be that the pre-service teachers did not have astronomy lessons at high school and university level (except Science teachers) after middle school. This shows that the knowledge learned in middle school is forgotten in the advancing process. Besides, that the pre-service teachers were more successful than the students after the project is such as to support this idea. Similarly, Bisard et al. (1994) has revealed that pre-service teachers and middle school students have approximately the same achievement level, that middle school students are even better in some subject areas and as a result of that the astronomy knowledge of the students do not change strikingly after middle school.

It is revealed by the studies conducted that similar misconceptions of teachers and prospective teachers in astronomy subjects are also observed in elementary students (Bisard et al., 1994; Lightman \& Sadler, 1993; Trumper, 2001, 2006). The best way to reduce alternative conceptions that the middle school students have is to determine the 
students' awareness of basic astronomy concepts and provide appropriate educational environment to that. Therefore, it is necessary for the Primary School teachers and Science teachers who will teach concepts related to astronomy in elementary education are required to have adequate knowledge (Kalkan \& Kıroğlu, 2007). As Pasachoff and Percy (2005) noted, astronomy concepts take place in the curricula of many countries but teachers either do not know enough about these concepts or have problems with teaching these concepts to students.

Significant differences between the pre- and post-project astronomy achievements of each group were determined. These differences were in favor of post-project. This result demonstrates that the conducted astronomy education project had a positive effect on increasing the students, pre-service teachers and in-service teachers' astronomy achievements.

When the participants' attitudes to astronomy are analyzed it is seen that there were significant differences before and after the project. First of all, when the changes of each group in themselves are analyzed it is determined that students, pre-service teachers and in-service teachers had positive increases in attitudes to astronomy after the project. This result suggests that the project is useful in improving attitudes to astronomy of participants'.

When the participants' attitudes to astronomy is analyzed by intergroup comparison; it is determined that while there is not a significant difference between the middle school students and the pre-service teachers' attitudes to astronomy, the teachers have more positive attitude to astronomy when compared with both the students and the pre-service teachers. When the attitude scores after the project are analyzed, it is seen that the students, the pre-service teachers and in-service teachers improved in parallel. In addition, it is seen that the difference between the pre-service teachers and in-service teachers before the project disappeared after the project. However, it is determined that the significant difference between the students and the teachers continued after the project.

There are many studies proposing to develop the cognitive and sensory skills of the students by associating the knowledge they learn at school with everyday life and by building their own models (Gilbert, 2004; Sarıkaya, Selvi \& Bora, 2004; Gümüş, Demir, Koçak, Kaya \& Kırıc1, 2008). Besides, there are studies showing that the science teaching is effective by doing experiments and that the environments such as planetarium, observatory and outdoor implementations facilitate learning (Freedman, 1997; Heather, 1999; Türk \& Kalkan, 2015a). As a result of this project, the students, pre-service teachers and in-service teachers were ensured to improve a positive attitude to astronomy and have an increase in astronomy achievement through planetarium, observatory, hands-on activities and modeling activities by letting them do the activities by themselves and understand abstract subjects as concrete.

First of all concrete-physical-scale models, 3D simulation modeling or planetarium media should be used in the training of teachers and pre-service teachers considering astronomy concepts as quite abstract ones, and they should be clearly taught how to use such models-modeling within the classroom or in training. Thus, it will be more likely to teach astronomy concepts which are difficult to teach through lectures on the board in a two-dimensional way to the students who are in the concrete operations period through alternative methods appropriate to the constructivist approach (Türk \& Kalkan, 2015a).

\section{Research Limitations and Future Directions}

It is considered to be useful for the Primary School teachers and Science teachers who are supposed to teach astronomy subjects in elementary school to receive training in astronomy subjects in the faculties of education. Therefore, astronomy lesson should definitely be included in the department of Primary School teaching programs. In addition, increasing the period of astronomy lesson in Science Teacher undergraduate program is also considered to be useful. Thus, pre-service teachers will be provided to have adequate knowledge on these subjects before they start their teaching career.

In addition; it is considered to be useful in terms of improving the quality of astronomy teaching in science teaching to give in-service training to the in-service teachers to be equipped with new knowledge and teaching methods on basic astronomy topics; implement teacher support programs in cooperation with higher education institutions and give a chance to the teachers to join the astronomy lessons in Science Teacher undergraduate programs.

Experimental studies with control groups can be conducted in further studies in order to evaluate the results obtained from the astronomy education projects better. Thus, the effectiveness of different learning environments and methods can be tested in astronomy education projects.

Increasing the number of such education projects can help the students to avoid prejudices about learning astronomy, to understand that astronomy is a part of everyday life and to understand that astronomy means to understand the universe. At the same time, longer projects and more field activities can present more effective results in the students' cognitive and affective learning. 
The project is considered to be a model for astronomy education projects in terms of combining different learning environments and teaching methods.

\section{Acknowledgments}

This work was funded by STRCT (The Scientific and Technological Research Council of Turkey), Project No. $115 \mathrm{~B} 224$.

A part of this study were presented as oral presentation at the " $1{ }^{\text {st }}$ International Lifelong Learning and Leadership Conference-ICLEL 2015"

\section{References}

Balım, A. G., Çeliker, H. D., Türkoğuz, S., \& Kaçar, S. (2013). The effect of reflections of science on nature project on students' science process skills. Journal of Research in Education and Teaching, 2(1), 149-157.

Bisard, W. J., Aron, R. H., Francek, M. A., \& Nelson, B. D. (1994). Assessing selected physical science and earth science misconceptions of middle school through university preservice teachers: Breaking the science "Misconception Cycle". Journal of College Science Teaching, 24, 38.

Büyüköztürk, Ş. (2007). Handbook data analysis for social sciences, (7th ed.), Ankara: Pegem A Publishing.

Büyüköztürk, Ş. (2010). Handbook data analysis for social sciences: Statistics, research design, SPSS and comments. Ankara: Pegem A Publishing.

Can, A. (2014). Quantitative data analysis with SPSS research process. (2nd ed.). Ankara: Pegem Akademi

Cohen, J. (1988). Statistical power analysis: A computer program. Routledge.

Creswell, J. W. (2008). Research design: Qualitative, quantitative, and mixed methods approaches. SAGE Publications.

Erdogan, M. (2011). The effects of ecology-based summer nature education program on primary school students' environmental knowledge, environmental affect and responsible environmental behavior. Educational Sciences: Theory and Practice, 11(4), 2233-2237.

Fraenkel, J. R., Wallen, N. E., \& Hyun, H. H. (2012). How to design and evaluate research in education. (8tht ed). New York: Mc Graw Hill.

Freedman, P. M. (1997). Relationship among laboratory instruction, attitude toward science, and achievement in Science knowledge. Journal of Research in Science Teaching, 34, 343-357. http://dx.doi.org/10.1002/(SICI)1098-2736(199704)34:4<343::AID-TEA5>3.0.CO;2-R

Gilbert, J. K. (2004). Models and modelling: Routes to more authentic science education. International Journal of Science and Mathematics Education, 2(2), 115-130. http://dx.doi.org/10.1007/s10763-004-3186-4

Gümüş, İ., Demir, Y., Koçak, E., Kaya, Y., \& Kırıcı, M. (2008). The effects of model-teachıng on students success. Erzincan Journal of Education, 10(1), 65-90.

Güler, T. (2009). The effects of an ecology based environmental education on teachers' opinions about environmental education. Education and Science, 34(151), 30-43.

Heather, P. (1999). Experiential environmental education for primary aged-children (ERIC Document Reproduction Service No. ED 471 723).

Kalkan, H. \& Kıroğlu, K. (2007). Science and nonscience students' conceptions of basic astronomy concepts in preservice training for education teachers. Astronomy Education Review, 6 (1), 15-24. http://dx.doi.org/10.3847/AER2007002

Kalkan, H., Kiroğlu, K., Türk, C., Bolat, M., Kalkan, S., \& Aslantürk, A. (2014). Basic astronomy concepts in the footsteps of Eratosthenes. Procedia-Social and Behavioral Sciences, 116, 3731-3739. http://dx.doi.org/10.1016/j.sbspro.2014.01.832

Lightman, A., \& Sadler, P. (1993). Teacher predictions versus actual student gains. The Physics Teacher, 31, 162-167. http://dx.doi.org/10.1119/1.2343698

Oğuroğlu, İ., Alkan, H., \& Gündoğdu, E. (2010). Nature education project in Isparta protected areas I: Perceptions and expectations of participants. III. National Black Sea Forestry Congress, 20-22 May, 11; 144-152. 
Pasachoff, J. M., \& Percy, J. R. (Eds.). (2005). Teaching and learning astronomy. Cambridge: Cambridge University Press. http://dx.doi.org/10.1017/CBO9780511614880

Sagan, C. (1980). Cosmos, United States, Random House.

Sarıkaya, R., Selvi, M., \& Bora D., N. (2004). The importance effect of the use of models in teaching of mitosis and meiosis. Kastamonu Education Journal, 12(1), 85-88.

Trumper, R. (2001). A cross-age study of senior high school students' conceptions of basic astronomy concepts. Research in Science and Technological Education, 19 (1), 97-109. http://dx.doi.org/10.1080/02635140120046259

Trumper, R. (2006). Teaching future teachers basic astronomy concepts—seasonal changes—at a time of reform in science education. Journal of Research in Science Teaching, 43(9), 879-906. http://dx.doi.org/10.1002/tea.20138

Türk, C., \& Kalkan, H. (2015a). The effect of planetariums on teaching specific astronomy concepts. Journal of Science Education and Technology, 24(1), 1-15. http://dx.doi.org/10.1007/s10956-014-9516-6

Türk, C., \& Kalkan, H. (2015c). Astronomy attitude scale: Development, validity and reliability. Journal of Studies in Education, 5(4), 23-50.

Türk, C., \& Kalkan, H. (2015b). Developing an achievement test for astronomy education. Journal of Studies in Education, 5(3), 89-112. http://dx.doi.org/10.5296/jse.v5i3.8099

Vosniadou, S., \& Brewer, W. F. (1985). The problem of knowledge acquistion. Techinical report No. 348. University of Illinois at Urbana Champaign. 